\title{
Political brand image: an investigation into the operationalisation of the external orientation of David Cameron's Conservative brand
}

\section{Pich \& G. Armannsdottir}

To cite this article: C. Pich \& G. Armannsdottir (2015): Political brand image: an investigation into the operationalisation of the external orientation of David Cameron's Conservative brand, Journal of Marketing Communications, DOI: 10.1080/13527266.2015.1072577

To link to this article: http://dx.doi.org/10.1080/13527266.2015.1072577

\section{Published online: 01 Sep 2015.}

\section{Submit your article to this journal $\square$}

Џ Article views: 13

Q View related articles ¿

\section{View Crossmark data ¿}




\title{
Political brand image: an investigation into the operationalisation of the external orientation of David Cameron's Conservative brand
}

\author{
C. Pich and G. Armannsdottir \\ Nottingham Business School, Nottingham Trent University, Burton Street, Nottingham, UK
}

\begin{abstract}
This paper seeks to address the limited understanding of how to operationalise the external brand image of a political brand. More specifically, this research critically assesses the transfer potential of the six variables of brand image by Bosch, Venter, Han and Boshoff to deconstruct the UK Conservative Party brand from the perspective of young people aged 18-24 years during the 2010 UK General Election campaign. This research demonstrates the applicability of the six variables otherwise known as the 'brand image framework' to the political environment. However, the application of the brand image framework in its original conceptualisation proved problematic. Many of the brand image variables were clarified, rearticulated and simplified to address the political context. This refined conceptualisation provided an in-depth understanding of how to investigate the political brand image of David Cameron's Conservative Party. This study addresses the paucity of research that operationalises external brand image and provides practitioners and academics within and beyond the context of political branding a mechanism to understand the external orientation of brands. This research may also be used by political and non-political brands as a basis to explore external brand image and compare its consistency with internal brand identity.
\end{abstract}

\section{ARTICLE HISTORY}

Received 22 April 2014 Accepted 8 July 2015

\section{KEYWORDS}

Brand image; Conservative Party; Political brands

\section{Introduction}

The conceptualisation of political parties, ideologies and candidates as 'brands' has become an accepted proposition and a recognised area of research that continues to evolve and develop (French and Smith 2010; Harris and Lock 2010; Lock and Harris 1996). Rawson (2007) argued that political brands are powerful important devices, which need to be thoroughly understood (Needham 2006; Phipps et al. 2010; Van Ham 2001). Political brands can be seen as a trinity of three elements, including the party leader, political party and party policy (Butler et al. 2011; Davies and Mian 2010; Smith and French 2011). Existing research has tended to focus on one (Smith and French 2011) or two aspects (Davies and Mian 2010) of the trinity, neglecting the exploration of all three elements of the political brand (Pich et al. 2014). Political branding, especially with a focus on all three elements deserves more attention (Peng and Hackley 2009; Rawson 2007; Reeves et al. 2006; Robinson 2004; Schneider 2004; Smith 2009; Van Ham 2001). More specifically, research focusing on the exploration of external political brand image remains limited with explicit calls for additional research in this area (Guzman and Sierra 2009; Schneider 2004; Smith 2001; Smith and French 2011). However, there are very few models or frameworks that 


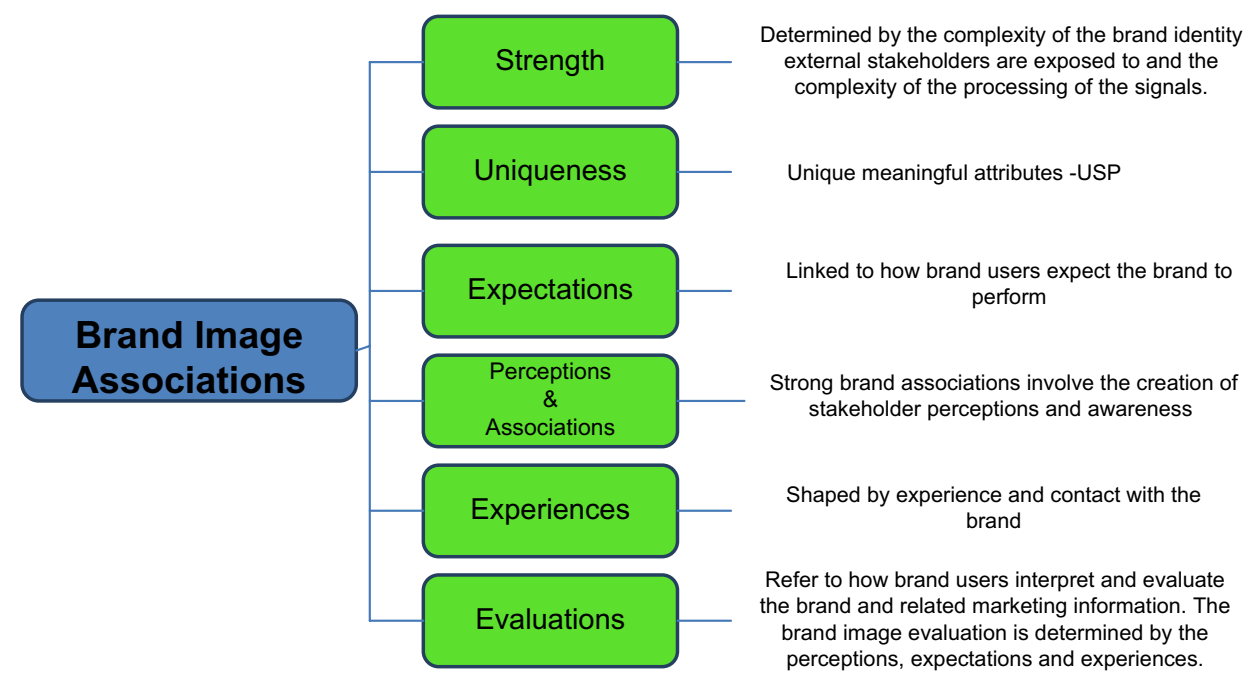

Figure 1. Depiction of the six variables of brand image formulated from Bosch et al. $(2006 a, 11)$.

promote the deconstruction and understanding of brand image. Therefore, this paper will seek to critically apply the brand image framework (Bosch et al. 2006a) in exploration of the three elements of the UK Conservative Party which will highlight its 'transfer potential' (Schneider 2004, 60) to the context of political branding.

\section{Brand image}

Brand image has been defined as 'the set of mental representations, emotional and/or cognitive an individual or a group of individuals ascribe to a brand' (Mengxia 2007, 36). Further, brand image can be seen as a set of perceptions about an organisation, product or brand developed in the mind of the consumer (Bosch et al. 2006b; Chen 2010; Einstein 2008; Morgan et al. 2002). This external imagery can be problematic for a brand's creator to manage, given that it cannot have full control of the external stakeholders thought process (Nilson and Surrey 1998; Petromilli, and Michalczyk 1999; Rekom et al. 2006). This demonstrates that brand image is complex and broad, with various conceptualisations across the marketing literature (Aaker and Joachimsthaler 2002; Henrik and Fredrik 2006; Keller 1993; Knox and Freeman 2006; Poiesz 1989). Brand image, therefore, is how the brand is understood. This is in contrast to brand identity. Brand identity has been defined as the internally envisaged aspirations communicated to the target audience (Pich et al. 2014). de Chernatony $(2007,47)$ argues that there is a need to understand 'the way customers perceive the brand, since their perceptions may be different from the intended projections.' Therefore, understanding the external associations and perceptions will not only generate deeper insight into a brand, but also highlight whether the understood external image is coherent with the aspired internal identity.

McEnally and de Chernatony (1999) call for a greater understanding of the image creation process from a consumer perspective. Furthermore, insight into brand image requires greater elaboration and more empirical research to strengthen this area of study (Alsem and Kostelijk 2008; Chen 2010; Cretu and Brodie 2007; Guzman and Sierra 2009; Henrik and Fredrik 2006; Johns and Gylmothy 2008; Knox and Freeman 2006; Poiesz 1989; Smith 2001). The existing literature tends to focus on internal brand identity (Davies and Chun 2002) and often poorly conceptualises brand image in comparison (Ross and Harradine 2011; Saaksjarvi and Samiee 2011; Srivastava 2011). Therefore, existing brand image research tends to neglect the development and assessment of brand image frameworks. This highlights a specific problem of how to deconstruct or operationalise brand image insights, given the limited frameworks in which to explore brand image (Aaker and Joachimsthaler 2002; Johns and Glymothy 
2008; Gordon 1999 cited in Cowley 1999; Bosch et al., 2006a; Ross and Harradine 2011; Saaksjarvi and Samiee 2011; Srivastava 2011). The existing limited frameworks are often descriptive rather than applied (Gordon 1999), and often indistinct with little grounding in existing brand image research (Aaker and Joachimsthaler 2002; Johns and Glymothy, 2008; Ross and Harradine 2011; Saaksjarvi and Samiee 2011; Srivastava 2011).

Bosch et al. (2006a) identified six variables from the existing literature on brand image and formulated a framework to explore and operationalise the image of a brand from an external perspective. According to Bosch et al. (2006a), the six-variable framework is grounded in the existing literature on brand image (Coop 2005; Keller 1993; Nandan 2005; Nilson and Surrey 1998; Smith 2001; Van Gelder 2003). Moreover, the six components of brand image, namely strength, uniqueness, expectations, perceptions and associations, experiences and evaluations are said to shape brand image (Bosch et al. 2006a). A visual aid depicting the six variables of brand image framework can be seen in Figure 1.

According to Bosch et al. (2006a), Strength is determined by the extent and complexity of the brand identity signals external stakeholders are exposed to and the complexity of decoding the signals. Bosch et al. (2006a) proposed Uniqueness as an important variable of brand image, which includes identifying unique meaningful attributes which distinguishes the brand, thus creating a competitive advantage. The uniqueness of the brand should also serve as a reason why stakeholders should embrace the brand, (Bosch et al. 2006a). The third variable outlined by Bosch et al. $(2006 \mathrm{a}, 14)$ is the idea of expectations; specifically how consumers expect the brand to perform. These prospective attributes provide insight into the outlook consumers associate with the brand. The fourth variable explores the perceptions and association consumers ascribe to brands (Bosch et al. 2006a), which may also highlight brand awareness and a greater understanding of reasoned and emotional brand image attributes. The experiences variable refers to the contact the consumer has with the brand. The final brand image variable, evaluations, is determined by the expectations, perceptions and associations and experiences of the brand in question.

The framework outlined in Bosch et al. (2006a) was formulated and employed as part of a research study to explore the external brand image of a higher educational institute in South Africa. This suggests that the framework (Bosch et al. 2006a) seems to offer an operational and systematic approach to deconstruct brand image. However, the six variables or 'brand image framework' has not been extended to other contexts to assess this proposition. Furthermore, only two of the six variables were actually applied in the original study (Bosch et al. 2006b). Therefore, this suggests that the original model has not been applied in its entirety, which raises questions about its functionality.

Three of the six variables 'uniqueness,' perceptions and associations' and 'expectations' are well defined and suggest simple application. However, the remaining three variables of the brand image framework appear vague and unclear in terms of conceptualisation. For example, the 'strength'variable is poorly defined and Bosch et al. (2006a) provide limited elaboration into the 'extent' and 'complexity' of brand identity signals. It is unclear whether the variable is designed to measure or test the strength of these espoused signals or designed to calculate the extent of these signals projected by brands. Similarly, the definition of the 'experiences' variable (Bosch et al. 2006a, 14) appears ambiguous with little explanation. The variable definition could only be clarified by tracing the sources and existing research to understand how this variable was developed (Keller 1993; Nilson and Surrey 1998). The conceptualisation of the 'evaluations' appears confusing and required deeper understanding before application. The conceptualisation is determined by considering the 'expectations', 'perceptions and associations' and 'experiences' variables and referred to how external stakeholders interpreted and evaluated the brand (Bosch et al. 2006a). This suggests that the 'evaluations' variable was merely an overview or replication of the previous applied variables, reapplied. Therefore, the brand image framework requires greater clarification and understanding. This can be achieved by critically applying all six variables in pursuit of deconstructing the external image of a brand. Ultimately, this research seeks to critically apply the Bosch et al. (2006a) model which will highlight its transfer potential to different contexts and the opportunity to develop a deeper understanding of a brand's external image. This in turn will go some way in addressing the call for a greater understanding of the image creation process from an external orientation (McEnally and de Chernatony 1999). 


\section{Political brand image}

This issue of how to deconstruct or operationalise brand image insights extends to the context of political brand image. Research in political brand image 'is of critical importance and as such merits further analysis' (Smith 2001, 992) and continues to be the case (French and Smith 2010; Needham and Smith 2015; Phipps et al. 2010; Smith and French 2011). The limited research political brand image research has tended to adopt a measurable, quantitative approach (French and Smith 2010; Mortimore et al. 2014). For example, Mortimore et al. (2014) measured the perceptions of the party leaders from the three main political parties in the UK and tested its relationship with the overall satisfaction for each leader. With the use of national survey data on voter's perceptions of party leaders during the 2010 UK General Election combined with satisfaction scores, Mortimore et al. (2014) highlighted the complexity and unpredictability of investigating political image in terms of leadership and positioning. Further, the work by Mortimore et al. (2014) highlighted the problematic nature of using image attributes designed for an earlier study, namely a published opinion poll. This suggests that before embarking on measurement and testing of brand image, future image research should consider in-depth exploration of the positioned perceptions, associations and imagery (Mortimore et al. 2014).

Furthermore, the scarcity of research devoted to political brand image does not detail how the associations and perceptions were uncovered from the perspective of external stakeholders (Mortimore et al. 2014; Peng and Hackley 2009; Smith 2001; Smith and French 2011). This is reinforced with calls for more exploratory research into political brand image (Davies and Mian 2010; Needham and Smith 2015; Peng and Hackley 2009; Smith and French 2011). Ultimately, there is limited understanding of a political brand from an external perspective that addressed the concept of 'brand image' profoundly. As there are limited frameworks to operationalise brand image research, the conceptualisation outlined by Bosch et al. (2006a) provides an opportunity to explore brand image and assess its applicability to the political context. Where existing branding tools and scales have been employed in existing political branding studies, they were often modified or extended to suit the unique environment (Guzman and Sierra 2009; Pich et al. 2014; Smith 2009). Nevertheless, in order to critically assess the 'transfer potential' (Schneider 2004, 60) of the six variables outlined by Bosch et al. (2006a) in exploration of the 'political' brand image, a political brand had to be presented as the unit of analysis.

\section{The Conservative Party}

The UK Conservative Party has been considered complex, diverse with often contrasting values and interests (Budge et al. 2001; Kavanagh 2000; Lee and Beech 2009). After three failed election defeats and three Conservative Party leaders, the UK Conservative Party failed in its attempt to modernise, reinvent and reconnect with the electorate, (Denham and O'Hara 2007; Smith 2009). In December 2005, David Cameron was elected as leader of the UK Conservative Party, proposing it was time to modernise (Denham and O'Hara 2007), unite the party and make the Party re-electable for the 2010 UK General Election. Furthermore, David Cameron attempted to reshape the UK Conservative Party and dispel negative associations, including the perceptions that the Party was out-of-touch, primarily focused on immigration and seen to represent the rich and privileged few (Ashcroft 2010; Helm 2010). Therefore, David Cameron's aim was to decontaminate the 'Tory brand' by addressing the party's negative brand image (Ashcroft 2010; Bale 2011; Jones 2010; Lee and Beech 2009). Subsequently, as this paper aims to critically assess the applicability of the brand image framework (Bosch et al. 2006a) to deconstruct the external view of a political brand, the UK Conservative Party during the 2010 UK General Election serves to contextualise this research. Further, this is the first occasion the brand image framework (Bosch et al. 2006a) has been applied and critically assessed in the context of political branding.

\section{Methodology}

As this research set out to critically assess the applicability of the six brand image variables (Bosch et al. 2006a) by exploring the UK Conservative Party brand from an external perspective, focus group 
Table 1. Sample of participants aged 18-24.

\begin{tabular}{|c|c|c|c|c|}
\hline Participant code & Political identification & Education level & Place of origin & Date of focus group \\
\hline P1FG1 & Conservative & PhD Student & North Yorkshire & 23rd March 2010 \\
\hline P2FG1 & Floating voter & Undergraduate & East riding of Yorkshire & \\
\hline P3FG1 & Floating voter & PhD Student & Buckinghamshire & \\
\hline P4FG1 & Floating voter & PhD Student & Newcastle & \\
\hline P5FG1 & Labour & Undergraduate & Liverpool & \\
\hline P1FG2 & Labour & A-level & Nottingham & 13th April 2010 \\
\hline $\mathrm{P} 2 \mathrm{FG} 2$ & Conservative & A-level & Nottingham & \\
\hline P3FG2 & Unknown & A-level & Nottingham & \\
\hline P4FG2 & Labour & A-level & Nottingham & \\
\hline P5FG2 & Floating voter & A-level & Nottingham & \\
\hline P6FG2 & Conservative & A-level & Nottingham & \\
\hline P7FG2 & Floating voter & A-level & Nottingham & \\
\hline P8FG2 & Labour & A-level & Nottingham & \\
\hline P1FG3 & Unknown & A-level & Nottingham & 13th April 2010 \\
\hline P2FG3 & Unknown & A-level & Nottingham & \\
\hline P3FG3 & Unknown & A-level & Nottingham & \\
\hline P4FG3 & Conservative & A-level & Nottingham & \\
\hline P5FG3 & Unknown & A-level & Nottingham & \\
\hline P1FG4 & Floating voter & GCSE & Nottinghamshire & 14th April 2010 \\
\hline P2FG4 & Floating voter & GCSE & Nottinghamshire & \\
\hline P3FG4 & Conservative & GCSE & Nottinghamshire & \\
\hline P4FG4 & Floating voter & GCSE & Nottinghamshire & \\
\hline P1FG5 & Floating voter & PhD Student & London & 19th April 2010 \\
\hline P2FG5 & Green party & PhD Student & Cambridgeshire & \\
\hline P3FG5 & Floating voter & PhD Student & Newcastle & \\
\hline P4FG5 & Floating voter & PhD Student & Sheffield & \\
\hline P1FG6 & Liberal democrat & A-level & Nottinghamshire & 20th April 2010 \\
\hline P2FG6 & Floating voter & A-level & Nottinghamshire & \\
\hline P3FG6 & Liberal democrat & A-level & Nottinghamshire & \\
\hline P4FG6 & Floating voter & A-level & Nottinghamshire & \\
\hline P5FG6 & Floating voter & A-level & Derbyshire & \\
\hline P6FG6 & Floating voter & A-level & Nottinghamshire & \\
\hline P1FG7 & Liberal democrat & A-level & Maidenhead & 22nd April 2010 \\
\hline P2FG7 & Conservative & A-level & Maidenhead & \\
\hline P3FG7 & Tactical & A-level & Maidenhead & \\
\hline P4FG7 & Floating voter & A-level & Maidenhead & \\
\hline P5FG7 & Floating voter & A-level & Maidenhead & \\
\hline P6FG7 & Floating voter & A-level & Maidenhead & \\
\hline P7FG7 & Labour & A-level & Maidenhead & \\
\hline P8FG7 & Floating voter & A-level & Maidenhead & \\
\hline P1FG8 & Conservative & Graduate & East Riding of Yorkshire & 3rd May 2010 \\
\hline P2FG8 & Floating voter & Graduate & East riding of Yorkshire & \\
\hline P3FG8 & Floating voter & Graduate & Cambridgeshire & \\
\hline P4FG8 & Labour & Graduate & East Riding of Yorkshire & \\
\hline P5FG8 & Labour & Graduate & East riding of Yorkshire & \\
\hline P6FG8 & Floating voter & Graduate & Wakefield & \\
\hline
\end{tabular}

discussions were considered an appropriate data collection method. The goal of a qualitative researcher is to build a comprehensive picture of the respondent's background, attitudes, feelings and experiences from the perspective of the respondent (Schutt 2004; Warren and Karner 2005). Focus groups are conventionally used by qualitative researchers as a context in which to frame group discussions (Langford and McDonagh 2003; Warren and Karner 2005; Zikmund 2003). A focus group discussion is 'a well-planned research endeavour' (Stewart and Shamdasani 1990, 51), 'designed to obtain perceptions of the group members on a defined area of interest' (Langford and McDonagh 2003, 2) and regarded as an unstructured interview with a small group of participants, (Zikmund 2003). 'Focused' group discussions (Krueger 1998) have been described as 'unpredictable' and 'organic in nature' (Bloor et al. 2001, 19), and ideal for exploratory research (Bloor et al. 2001; Zikmund 2003). In addition, the focus group discussions were enhanced by projective techniques (Bond and Ramsey 2010; Pettigrew and Charters 2008), often used in qualitative research to gain a deeper understanding of the research area (Broeckelmann 2010). Furthermore, it has been argued that focus group discussions combined 
with projective techniques have the ability to generate a deeper understanding of perceptions and highlight deep-seated associations (Baines and Chansarkar 2002; Bloor et al. 2001; Flick 1998; Krueger 1998; Kvale 1996; Malhotra and Birks 2003).

Ultimately, 82-hour focus group discussions were conducted with a total of 46 young citizens aged 18-24 years from three locations in England (Maidenhead, Nottingham, and Hull). Focus groups were conducted March 2010 - May 2010; the last focus group conducted four days before polling day on 6th May 2010. Young citizens aged 18-24 years were selected as part of this study as they were specifically targeted by the UK Conservative Party following David Cameron's leadership election as they were considered an untapped market (Ashcroft 2005; Charles 2009). For example, 39\% of adults aged 18-24 years voted in the 2001 UK General Election, 37\% in the 2005 UK General Election and $44 \%$ in the 2010 UK General Election (Worcester et al. 2011). In 2001, 27\% of adults 18-24 years voted Conservative compared to 28\% in 2005 and 30\% in 2010 (Worcester et al. 2011). Therefore, this age group posed an opportunity for the Conservative Party. However, this segment constituted the weakest supporting group of the UK Conservative Party from 1992 to 2009 (Worcester et al. 2011). It was also considered the most disengaged of all the electoral segments (Dermody et al. 2010). Therefore, this segment of voters was considered an appropriate sample to frame the study. Gorman and Clayton (2005) argued that qualitative researchers tend to select a purposive sample technique as the aim is not to infer generalisations to the population, but to gain an understanding of a particular phenomenon from the perspective of specific groups of individuals (Alston and Bowles 2007; Daymon and Holloway 2011; Gorman and Clayton 2005; Zikmund 2003). Therefore, as this research had a specific purpose to explore the UK Conservative Party brand from the perspective of young adults aged 18-24 years; purposive sampling was deemed an appropriate sampling technique. Age therefore, was the only prerequisite for participation. Existing political affiliation or level of political engagement were not important factors to consider as this research aimed to explore the rich imagery associated with the political brand. Table 1 presents the participant, their political affiliation, and place of origin, level of education and the date when the focus group was conducted.

The process of cyclical development (Gillham 2005), which proposes a number of stages to go through in order to design, develop and assess research tools/techniques was adopted to strengthen the reliability of data collection (Boddy 2005). The focus group schedule was reviewed by specialists in focus group research, including a seminar leader from the 'Marketing Research Society' and a brand manager for Boots UK. Both specialists highlighted no issues with the schedule or projective technique activities. A pilot focus group was also conducted in accordance with the process of cyclical development (Gillham 2005).

The researcher independently transcribed and analysed the findings from the focus group discussions, which strengthened the validity and reliability of the interpretation process and offered a consistent approach to analysis (Bryman and Bell, 2003). In contrast, this could be seen as a limitation as the analytical process could be open to interpreter bias (Ramsey et al. 2006). However, this was ameliorated by following critical methods of interpretation, including echoic probing and the practice of cross-checking. Ultimately, this strengthened the reliability, internal-reliability and validity of the data collection, analytical process and interpretation of findings (Boddy 2005; Day 1989).

\section{Findings}

To reiterate, this study aimed to address the limited understanding of the operationalisation process of brand image in a political context from an external orientation. This was achieved by critically applying the findings to the six variables of the brand image; strength, uniqueness, expectations, perceptions and associations, experiences and evaluations (Bosch et al. 2006a). Further, the political brand was investigated using the'trinity' proposition focusing on the party leader, political party and party policy (Butler et al. 2011; Davies and Mian 2010; Smith and French 2011). Consequently, the brand image framework served as a pragmatic and operational tool to deconstruct the political brand image of the UK Conservative Party. A visual aid depicting the key applied findings to the brand image framework can be seen in Figure 2. 


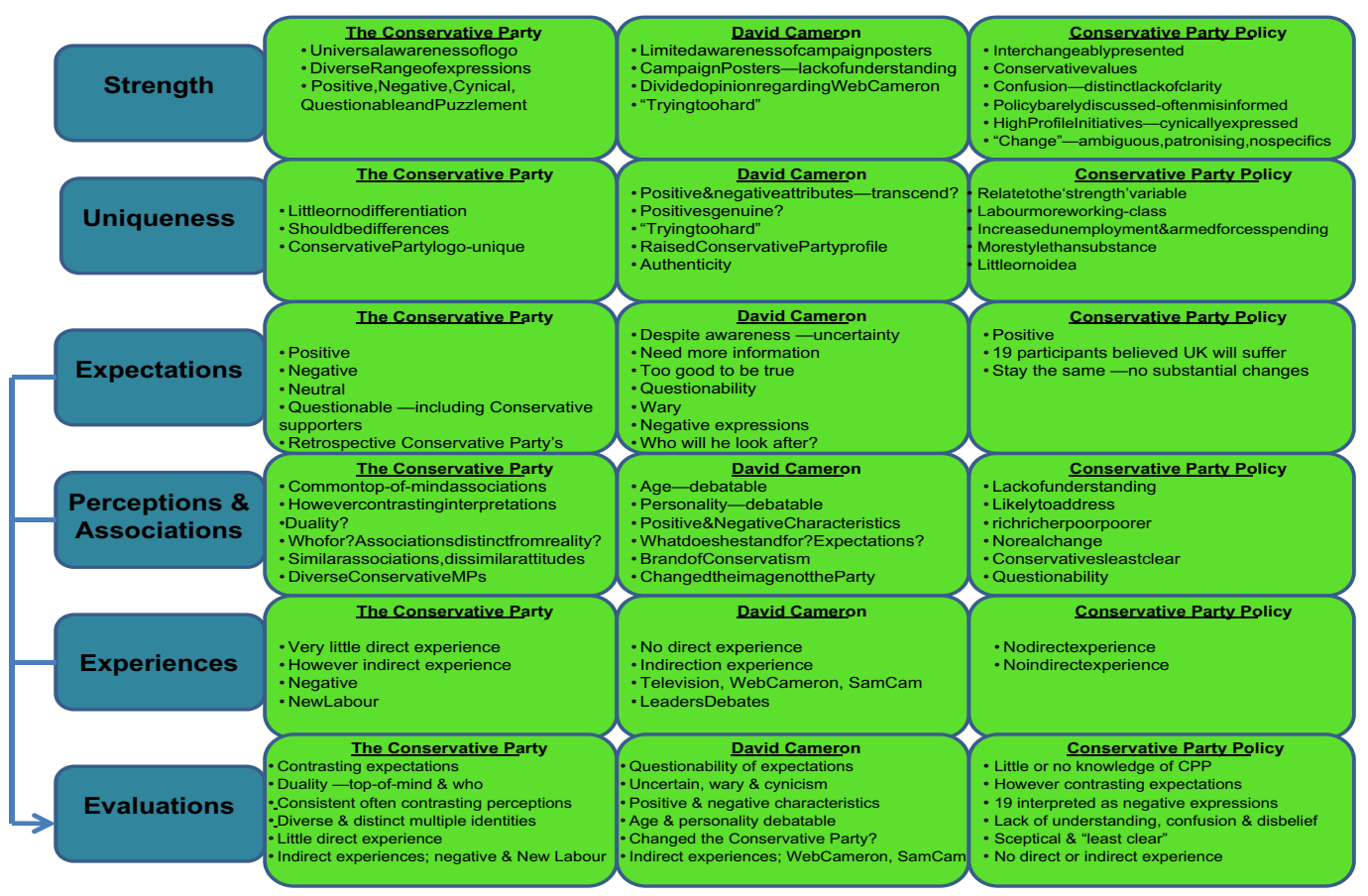

Figure 2. The brand image of the UK Conservative Party from the perspective of young citizens aged 18-24 years from across England.

\section{Strength}

The rearticulated strength variable explored the internally projected brand identity signals, discussed participant's awareness which generated a deeper understanding of external stakeholder's opinion and attitude of UK Conservative Party signals. These brand identity signals included the Conservative Party logo, positioning theme of 'change', communications tools such as WebCameron and a discussion on Conservative Party policy and values. The findings revealed that many external stakeholders to some extent were aware of Conservative'Party' signals. Further, it was no surprise that Conservative supporters revealed favourable opinions of Conservative signals and Labour supporters revealed critical views of Conservative signals. For example, a Labour supporting undergraduate from Liverpool highlighted puzzlement with the Conservative 'oak tree' logo;

we don't know the link between the Party and the logo ... would have thought [sic] more green [political party] but didn't think that was Tory policy. (P5FG1)

In contrast, Conservative supporting participants projected positive interpretations highlighting the tree represented 'change' (P6FG2), 'future, new beginnings' (P1FG1), with one participant liking the Conservative Party logo due to its simple qualities, (P3FG4). However, many floating voters highlighted limited knowledge and confusion with Conservative brand identity signals. For example, a floating voter from Buckinghamshire thought the tree was 'creative ... child-like ... not sure what it is meant to symbolise' (P3FG1). This lack of clarity and debate was also associated with David Cameron's web-based communication tool; 'WebCameron', which allowed behind the scenes access into David Cameron's everyday family life. 'WebCameron' was also seen as fake, superficial and actually alienated a number of participants. A floating voter from Nottinghamshire believed the WebCameron podcasts'seem fake and make him look arrogant' (P6FG6). Similarly, another floating voter from Maidenhead revealed that David Cameron's use of podcasts highlighted the party was 'trying too hard ... puts people off" (P5FG7). This sense of critique and confusion also linked to the nationwide poster campaign in part 


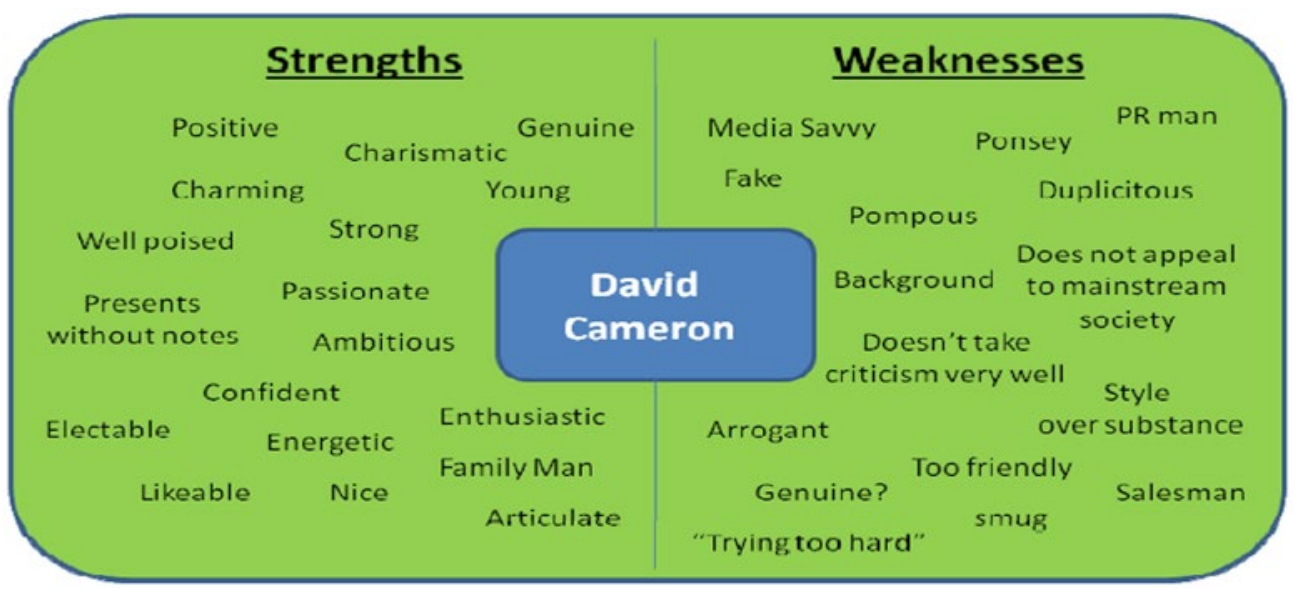

Figure 3. Strengths and Weaknesses presented in reference to David Cameron.

alienated rather than attracted participants to the UK Conservative Party. For example, a floating voter from Nottinghamshire argued 'what do they mean with the posters ... they should be telling us what they will do ... at first I thought it was Gordon Brown's party' (P32FG4).

In terms of 'Policy', very few participants provided illustrations or awareness of Conservative Policy. For example, participants were confused and 'didn't really know' (P3FG2) Conservative Party policy or values, with one participant suggesting that the Party did not have any policies, (P5FG1). One floating voter from Yorkshire revealed;

I don't know what he stands for ... don't know any of his policies. Maybe [he] should tell me some of his policies. (P2FG1)

Similarly, a floating voter from Derbyshire believed;

I think people won't vote for him because they don't actually know what will happen under a Conservative government. (P5FG6)

Nevertheless, the idea of 'change' was a major occurring theme illustrated by participants, yet it lacked specifics, understanding and believability and argued to be'patronising' by one participant. For examples, a Conservative supporter from Nottingham highlighted that the 'idea of change was coming across but we need more information'. This ambiguity of 'change' was shared by another Conservative supporter who argued 'uncertain of how he is going to make a difference' (P5FG6). This was supported by participant from Maidenhead who revealed:

Cameron keeps talking about change but not many people know what he's going to do. No specifics. Don't think he's got a real idea of what he means by change. (P7FG7)

Subsequently, many participants of all political affiliation were conscious of some Conservative brand identity signals which have the ability to play a role in brand image creation (Bosch et al. 2006a; Nandan 2005). However, the interpretation and understanding of the brand identity signals were often inconsistent from the intended projection (de Chernatony 2007). Therefore, calls for greater clarity and specific detail would support the recognised brand identity signals which would strengthen the Conservative Party brand image in the mind of external stakeholders.

\section{Uniqueness}

The uniqueness variable was broadly articulated as the unique meaningful attributes external stakeholders ascribed to the UK Conservative Party brand (Bosch et al. 2006a). In addition, the uniqueness of the brand should also serve as a reason why stakeholders should embrace the brand (Bosch et al. 2006a). However, this research highlighted that the UK Conservative Party brand failed to clearly communicate unique meaningful attributes to differentiate itself from political competitors in the mind of external 
stakeholders. For example, one Green supporting postgraduate participant considered 'I don't see any actual difference, people [politicians] are the same ... but they're supposed to be different' (P2FG5). Similarly, one floating voter argued the Conservatives were a little superficial, focusing more on style than substance and expressed 'when I hear about Labour I hear more about what they're going to do [sic] whereas Cameron and his silly campaigns look good but provide no detail or specifics' (P2FG1). Despite participants believing there was little or no difference between mainstream political parties, participants did recognise the distinction between political party leaders. UK Conservative Party leader David Cameron was seen as a positive and negative unique attribute of brand image evident in Figure 3.

It was also found that 'David Cameron' was one of the first associations participants expressed in relation to the UK Conservative Party, despite participants expressing contrasting attitudinal perspectives. A number of participants of all political affiliation conceived the idea that with David Cameron as leader, it made participants more interested (P2FG2), raised the profile of the Conservative Party (P1FG6), 'wouldn't have considered voting for the Conservatives if it wasn't for Cameron' (P5FG6) and 'made me look at the Tories differently' (P3FG3). Therefore, David Cameron highlighted more unique associations than the'Party'. Participants demonstrated a limited awareness of Conservative Party policy, were often confused and participant's proposed Conservative Party policy lacked clarity and understanding. Nevertheless, several participants revealed small distinctions between the Labour Party and the Conservative Party in terms of policy and associations. One floating voter from Nottinghamshire believed the Labour Party was'more working-class' (P4FG4), with more of a focus on employment, public and social welfare, higher taxes and bridging the social class divide. Contrastingly, a Conservative supporting participant considered a Conservative administration would increase spending on unemployment and the armed forces (P3FG4), with various external stakeholders associating privatisation, focus on the individual, the idea of change and cutting the deficit attributes in relation to the Conservative Party.

\section{Expectations}

The expectations variable referred to how external stakeholders expected the UK Conservative Party to perform if the party were successful at the 2010 UK General Election. Many participants were uncertain of what to expect from a Conservative Party in government as they had nothing to base their expectations on. For example, a Conservative supporting participant from Nottingham revealed 'I wonder what will happen' (P6FG2), 'great, what do they do then' (P2FG4) expressed by a floating voter from Nottinghamshire and 'I know he looks better on TV but what the hell is this Big Society ... is he Thatcher in disguise' (P3FG7), proposed by a tactical voter from Maidenhead. This often resulted in retrospective thinking and associating the party with stereotypical perceptions. For example, a Labour supporting participant stated that citizens will'start guessing what he's [Cameron] going to do, [sic] so retrospectively' and because of the lack of substance and clarity, retrospective thinking will be used to determine what to expect from a Conservative government (P4FG8). This idea was also presented by a floating voter from Nottinghamshire whereby'people with little or no interest in politics only know of Conservatives under Thatcher [Margaret]. These stories are passed down generations' (P4FG4), therefore a retrospective rather than a prospective outlook. Despite Cameron's increased awareness in the minds of participants, the majority raised a series of questions rather than answers relating to expectations. This was articulated by a floating voter (A-level) from Nottinghamshire'l think people won't vote for him because they don't actually know what will happen under a Conservative government. People aren't sure if Cameron will go easy on the posh people' (P5FG6). This lack of clarity was also expressed by a Conservative supporting A-level student from the City of Nottingham whereby the 'idea of change is coming across but we need more information' (P2FG2).

In terms of 'policy', many participants including two Conservative supporters considered the UK would pretty much look the same under a Conservative administration in comparison with a Labour government. For example, a floating voter (postgraduate) from London conceived 'no change to my everyday life, so UK will not change from my perspective ... unless they scrap the NHS pensions' (P3FG1). Furthermore, a floating voter (young professional) from Cambridgeshire argued that the UK will look 


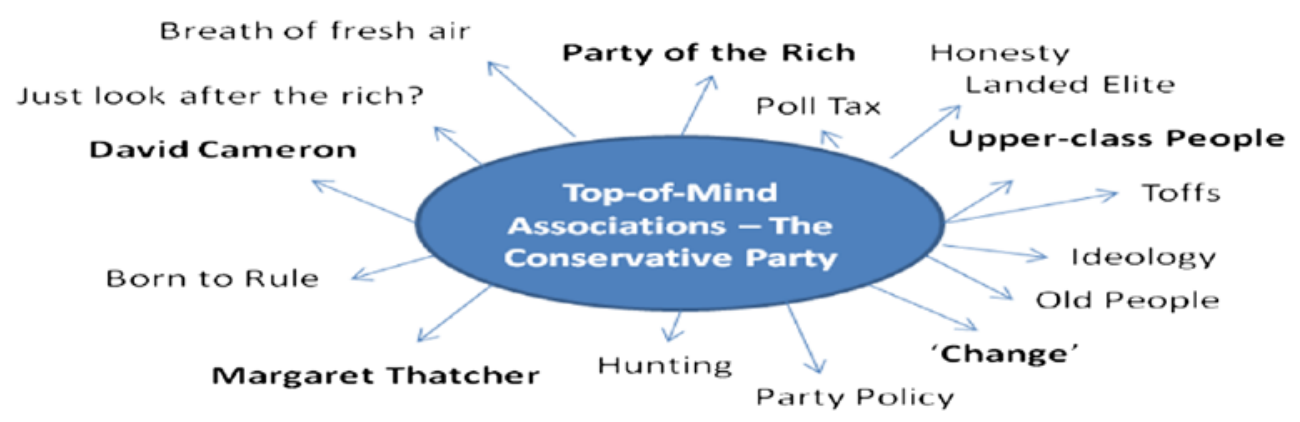

Figure 4. Common themes identified in association with the UK Conservative Party.

'the same' under Conservative rule, however stated '[sic] but myself and my family may be poorer' (P3FG8) if the Conservatives are elected. However, several participants highlighted positive and negative associations in relation to expectations of Conservative 'policy'. For example, a Conservative supporter with no higher education believed Conservative policy would equate to 'more support for forces \& NHS' and 'tax increase not taking place' (P3FG4). In contrast, a young professional floating voter from Wakefield expressed a Conservative UK would lead to 'oppressed poor, stagnant economy, spending cuts and class divide', in contrast to 'all the same, safe pair of hands - Brown [Gordon] strong future' (P6FG8). Therefore, despite the large number of respondents highlighting little knowledge of what to expect from Conservative policy, a small number highlighted emotive expectations, some in line with their political perspective.

\section{Perceptions and associations}

This variable included the perceptions and associations external stakeholders ascribed to the UK Conservative brand. It was revealed that the UK Conservative 'Party' had not managed to completely dispel the party of the rich, privileged and upper-classes perceptions and associations and failed to demonstrate the desired inclusive image. Some of the key themes can be seen in Figure 4.

For example, a number of common themes were discovered, with the majority of respondents recalling David Cameron, Margaret Thatcher, Change, and Party of the Rich and Upper-class people. Furthermore, the top-of-mind associations revealed genuine support for the Conservative Party, for example, the 'party' was seen as 'a breath of fresh air - a positive change' (P6FG2), and also disclosed ideas of honesty, optimism (P1FG1), support for Conservative Party policy (P4FG3; P5FG3) and ideology (P1FG8). Therefore, the findings suggested that the 'Party' had come some way in refocusing the image of the UK Conservative Party and how the party was perceived by highlighting traditionally held perceptions but also the newer Cameron-inspired values. Many participants including Conservative supporters remained uncertain, confused and raised questions regarding 'who' the UK Conservative Party represents. For example, the 'Party' was perceived to represent the upper-class (P5FG1), wealthy individuals (P3FG2), posh people (P4FG4), rich bankers (P3FG5), rural (P2FG5), traditionalists (P3FG5), public school and from the'playing fields of Eton', (P7FG7). However, several participants including one Conservative supporter from the City of Nottingham proposed the Conservatives are for the middle-classes (P4FG3; P5FG3), and 'they're less the party of the rich but still have an association with the upper-classes because they used to represent them' (P2FG7). Therefore, the findings suggested that the perceptions and associations are incoherent with David Cameron's aim or 'task' for the UK Conservative Party to be perceived as an inclusive political party for everyone.

It was also found that there was a duality with the UK Conservative 'Party' brand which could be divided into the 'corporate' and 'individual' political brand. Several participants believed local members of Parliament (or local political brand) were often distinct, possessed their own identities, approachable and more trustworthy in comparison with the corporate. For example, William Hague MP (former 
Conservative Party leader 1997-2001) had an established supported identity compared with the national party because 'he's more North Yorkshire' and 'maybe because Hague is local MP' (P1FG8). A Labour supporting young professional also from East Riding of Yorkshire conceived Ken Clarke MP (Rushcliffe-Nottinghamshire) 'who is clearly wealthy (but) comes across as approachable' and well established (P4FG8). Therefore, 'individual' political brands were often more appealing and engaging compared with the 'corporate' Conservative Party.

David Cameron was perceived as different from previous Conservative leaders, dynamic and associated in part with new non-Conservative policy areas or un-Tory themes. However, despite many participants not knowing what David Cameron 'stood for' and projecting negative associations of the Conservative'Party', the majority of participants provided positive perceptions of the Conservative Party leader. To some participants, age was an important factor in association with David Cameron, with the expectation that the Prime Minister should be young, energetic and enthusiastic (P4FG3), and that a younger party leader would make participants relate to David Cameron more and vice versa (P5FG3). David Cameron was also said to hold more of a personality than the other political party leaders and was said to be friendly, with excellent communication skills, family orientated, approachable, amusing, talkative, likeable, passionate, a strong leader and charismatic.

Nevertheless, the 'perception' of Conservative Party policy was debatably expressed. The UK Conservative Party failed to address a lack of understanding, confusion and general disbelief that the party actually had 'policies' and failed to convince the participants that the party would adhere to party pledges. For example, one floating voter from Maidenhead (A-level) argued 'out of all the different parties the Conservatives are least clear about what they want and how can I support a party that I don't know what they stand for' (P6FG7). In addition, another floating voter from Maidenhead (A-level) argued that 'the Conservatives have lost their identity slightly' and this was down to the lack of clear policies (P5FG7). However, several external stakeholders positively perceived that the Conservative Party had renewed its reputation for economic competence, something dashed after 'Black Wednesday' and perceived to be tough on immigration. Nevertheless, this traditional Conservative theme of 'tough on immigration' was something David Cameron had attempted to distance the party from since his leadership in 2005 (Ashcroft 2010).

\section{Experiences}

The variable was subdivided into two areas; direct experiences and indirect experiences. Direct experience focused on the external stakeholder's own personal experience and contact, whereas indirect experience referred to external sources of information, for example, word of mouth, advertising or general communication. The majority of participants illustrated very little direct experience with the UK Conservative 'Party.' However, two 'self-proclaimed' Labour supporters expressed positive direct experience with their local Conservative Member of Parliament. This was contradictory to the negative associations and perceptions of the Conservative Party and pessimistic expectations of a hypothetical Conservative government. For example, a staunch Labour supporting participant argued 'I'm not a Tory but when I lived in Beverley had the best MP, [sic] know where he is and if I lived in Beverley I would vote for him' (P5FG8). Additionally, 'local MP's make a huge difference and are passionate about their area. By personally trusting and contacting local MP I can actually resonate with him' (P4FG8), despite being a Labour voter. This suggests that genuine direct experience may have the ability to attract a broader support base which goes beyond party politics. Furthermore, this strengthens the idea of distinction between the corporate and individual 'Party' brand. However, the findings also highlighted that direct and indirect experiences are often independent of the political brand's control. For example, a floating voter argued that'my mum went on the Poll Tax March ... if Thatcher is mentioned in my house all hell breaks loose' (P1FG4). Similarly, a floating voter from Maidenhead highlighted 'I feel when they [Conservatives] come to power they'll do what New Labour did and didn't actually stick to their word' (P6FG7). Therefore, indirect experiences can shape imagery associated with the UK Conservative'Party', which in turn could be problematic for political brands. 
Unsurprisingly, participants revealed a direct experience with David Cameron. Several participants highlighted a number of indirect experiences, such as viewing appearances of David Cameron on the morning television programme GMTV, his social media tool 'WebCameron' and the infamous Leaders Debates broadcast during the 2010 General Election Campaign. Similar to the uniqueness variable, the indirect experiences revealed positive and negative associations linked to David Cameron. For example, opinion was divided with WebCameron; attempting to normalise himself' (P5FG6), 'seems fake and makes him look arrogant' (P6FG6), 'trying too hard ... puts people off' (P5FG7) and 'trying to reach out to young people but kind of messing it up' (P2FG1). Participants had no direct or indirect contact with Conservative Party policy and this maybe down to the fact the Conservative Party had been in opposition for 13years since 1997.

\section{Evaluations}

The evaluations variable was determined by revisiting the expectations, perceptions and associations and experiences (Bosch et al. 2006a). Despite the repeatable nature of the evaluations variable, it allowed the applied findings to be clearly presented and it acknowledged the key points from each variable. This ultimately provided a broad overview of the brand image of the UK Conservative Party brand from the perspective of external stakeholders (citizens 18-24 years) minus the applied findings accommodated under the strengths and uniqueness variables. For example, the UK Conservative 'Party' to a certain extent failed to communicate a coherent, consistent and understandable political brand to external stakeholders aged 18-24 years. Nevertheless, the findings suggest that the UK Conservative'Party' had come some way in refocusing the image of their political brand with the idea of 'change' and association with 'David Cameron', who was often stronger and identifiable compared to the 'Party'. Unfortunately, this was often undermined by the limited understanding and questionable nature of Conservative Party 'policy'. Therefore, the UK Conservative Party brand image under the leadership of David Cameron can be considered complex, multifaceted and often contentious.

\section{Discussion}

Given there are very few models or frameworks that promote the deconstruction and understanding of brand image, this paper aimed to critically apply the brand image framework (Bosch et al. 2006a) in exploration of the three elements of the UK Conservative Party. This study also addresses the limited understanding devoted to political brand image which goes beyond the usual measurable, quantitative approach (French and Smith 2010; Mortimore et al. 2014). This study was the first occasion all six variables outlined by Bosch et al. (2006a) had been used to explore the external understanding of a brand. The original study by Bosch et al. (2006a, 2006b) conceptualised six variables however only applied two of the six variables. Further, Bosch et al. (2006a, 2006b) failed to provide rationale for only applying two of the six variables in the original study. If Bosch et al. (2006a, 2006b) had applied all six variables in the original study, then this may have highlighted the problematic nature with part of the framework in terms of functionality and operationalisation. This research therefore, highlighted that the original conceptualisation put forward by Bosch et al. (2006a) needed to be reconceptualised before application. Future research therefore should avoid the original conceptualisation due to its ambiguous, unclear and repetitive nature. Further, future research should consider this revised conceptualisation outlined in Table 2. This revised framework clearly opertationalises the image of a brand and provides a simplified mechanism to explore a political brand from an external perspective.

Following some refinement, this research demonstrated that the six variables of brand image (Bosch et al. 2006a) have significant'transfer potential' (Schneider 2004,60) in deconstructing the political brand of the UK Conservative Party. However, three of the six variables, namely uniqueness, perceptions and associations, and expectations required no adaptation to explore the three elements of the Conservative brand (party, leader and policy). The three variables were well defined and pragmatic in application with the aid of focus group discussions and projective techniques. However, it could be argued that 'uniqueness' equating to unique meaningful attributes should relate to all aspects of brand image. For example, all variables including strengths (physical brand identity signals), expectations, perceptions/ 
Table 2. The deconstruction of political brand image.

\begin{tabular}{|c|c|c|c|}
\hline $\begin{array}{l}\text { Brand image } \\
\text { variables }\end{array}$ & Perspective & $\begin{array}{l}\text { Political brand image variables - defi- } \\
\text { nition }\end{array}$ & Desired outcome \\
\hline Strength & External & $\begin{array}{l}\text { The 'strength' variable refers to the external } \\
\text { understanding and awareness of the brand } \\
\text { identity signals (for example physical com- } \\
\text { munication tools) projected by the political } \\
\text { brand. In the context of political branding; } \\
\text { the political brand is conceptualised as the } \\
\text { 'party','party leader' and 'party policy' }\end{array}$ & $\begin{array}{l}\text { External stakeholders should have a good } \\
\text { understanding and awareness of brand iden- } \\
\text { tity signals. Brand identity signals should be } \\
\text { clear and informative. Successful brands have } \\
\text { consistency between how brands are commu- } \\
\text { nicated and how they are understood }\end{array}$ \\
\hline Uniqueness & External & $\begin{array}{l}\text { 'Uniqueness' refers to unique meaningful } \\
\text { attributes and reasons why people should } \\
\text { support/adopt the brand. However, the } \\
\text { other four brand image variables should } \\
\text { offer unique meaningful attributes to } \\
\text { distinguish a political brand from competi- } \\
\text { tors, which should enhance success }\end{array}$ & $\begin{array}{l}\text { Political brands should communicate inter- } \\
\text { nally developed and envisaged meaningful } \\
\text { attributes to external stakeholders, with the } \\
\text { aim of linking the positive and focused attrib- } \\
\text { utes to the political brand }\end{array}$ \\
\hline Expectations & External & $\begin{array}{l}\text { 'Expectations' refers to how the external } \\
\text { stakeholders expect the political brand to } \\
\text { perform. This can be difficult for opposition } \\
\text { political brands and can be influenced by } \\
\text { the narrative set by political competitors }\end{array}$ & $\begin{array}{l}\text { Political brands should offer clear visions or } \\
\text { examples of what external stakeholders can } \\
\text { expect if the brand is elected into govern- } \\
\text { ment. This direction will offer understanding } \\
\text { and reduce anxiety. Further, it will allow } \\
\text { political brands a degree of control of their } \\
\text { vision and reduce the likelihood of external } \\
\text { stakeholders listening to narratives set by } \\
\text { political competitors }\end{array}$ \\
\hline $\begin{array}{l}\text { Perceptions } \\
\text { and associa- } \\
\text { tions }\end{array}$ & External & $\begin{array}{l}\text { This variable refers to the perceptions and } \\
\text { associations external stakeholders ascribe } \\
\text { to political brands. As political brands can } \\
\text { also be distinguished via corporate and } \\
\text { individual/sub-brands. Thus an individual } \\
\text { political brand can be contextualised as } \\
\text { the 'local party', candidate/politician 'local } \\
\text { leader' and 'local party policy' }\end{array}$ & $\begin{array}{l}\text { Political brands should consider how they are } \\
\text { currently perceived and understood before } \\
\text { attempting to reposition imagery attached } \\
\text { to the brand. This will highlight whether } \\
\text { perceptions and associations need to be } \\
\text { refined or changed if external understanding } \\
\text { is inconsistent with internal positioning. } \\
\text { Successful associations and perceptions are } \\
\text { positive, engaging and simple }\end{array}$ \\
\hline Experiences & External & $\begin{array}{l}\text { This variable refers to the external } \\
\text { stakeholders experience with the political } \\
\text { brand. This can be divided into direct } \\
\text { (external stakeholders own personal } \\
\text { experience/contact) and indirect (sources } \\
\text { of information such as word-of-mouth or } \\
\text { narratives by competitors) }\end{array}$ & $\begin{array}{l}\text { Political brands should utilise direct and } \\
\text { indirect experiences to connect or reconnect } \\
\text { with the electorate. This will develop external } \\
\text { brand image. Direct experience has the ability } \\
\text { to attract a broader support base which can } \\
\text { go beyond party politics. The utilisation of } \\
\text { 'experiences' can be used by corporate and } \\
\text { individual political brands. Political brands } \\
\text { should be aware of the complexity of attempt- } \\
\text { ing to control indirect experiences }\end{array}$ \\
\hline
\end{tabular}

associations and experience should communicate uniqueness in the mind of the consumer and provide consumers with meaningful attributes to distinguish a brand from competitors. 'Uniqueness' therefore should equate not only to a variable of brand image, but also a key element of all variables to ensure a clear and consistent external understanding of a brand. In terms of the UK Conservative Party, brand image failed in part to communicate clear points of differentiation for the 'Party' and 'Policy' compared to competitors; however, David Cameron was differentiated and possessed unique attributes in the minds of participant. The 'expectations' variable also offered pragmatic qualities in terms of application. Nonetheless, the expectations variable highlighted the problematic nature for opposition political brands (Smith 2005) as there is little/no evidence of performance in government for voters to base their expectations. This can often result in retrospective thinking or the premise of unanswered questions surrounding the political brand and this was the case with the UK Conservative Party. The 'perceptions and associations' variable provided simple transference as this highlighted that the UK Conservative brand image was a multidimensional construct of traditional and stereotypical imagery combined with un-Tory themes led by a dynamic party leader. This variable also highlighted the potential of individual or local party brands in strengthening voter engagement and beyond party politics support. 
Despite the significant and pragmatic transfer potential of uniqueness, perceptions/associations and expectations variables, the strength variable, experiences variable and evaluations variable required adaptation from their original conceptualisation before application. For example, the original definition of the 'strength' variable was unclear and poorly defined. Further, the original definition suggested the variable was designed to measure/test the strength of brand identity signals; however, Bosch et al. (2006a) failed to explain how this could be achieved. Therefore, as this paper adopted an exploratory approach, the aim was to understand rather than test/measure the attitudes and imagery attached to the UK Conservative Party brand identity signals from the perspective of participants. This simplified definition provided clarification during the application process. Thus, the original definition of the 'strength' variable by Bosch et al. (2006a) was flawed. The revised strength variable highlighted that participants were aware of UK Conservative Party brand identity signals; however, participants projected conflicting opinions and indicated some confusion in terms of interpretation. Furthermore, many participants believed David Cameron had raised the profile of the party. Nevertheless, uncertainty and unanswered questions were associated with the UK Conservative Party brand.

Similarly, the original definition of the 'experiences'variable was ambiguous and only acquired clarity after tracing the sources and existing research. This in turn weakens the rigour and questions the validity of the original conceptualisation by Bosch et al. (2006a). With this in mind, future studies should avoid the original definition and consider the updated version set out in this study as this will provide deeper understanding of how to apply the variable to deconstruct political brand image. For example, once clarified and updated, the 'experiences' variable could be divided into direct and indirect experiences. As a result, it was found that very few participants had direct experience of the UK Conservative Party brand. However, several participants revealed their direct experience of the localised UK Conservative brand had the potential to have a positive impact on the national/corporate UK Conservative Party brand. This highlighted a dual nature to the UK Conservative Party brand and the ability to attract a broader support base beyond party politics. Existing research argued that the brand image of individual political brands is influenced by the 'corporate' political brand of the political party (Phipps et al. 2010). Therefore, 'corporate' political brands of political parties have the ability to hinder local politician's reputation and in the case of this study, the positive brand image of the local Member of Parliament outweighed the negative brand image of the UK Conservative Party. Participants also revealed indirect experiences with the political brand, which was often independent of the Party's control. Political entities should be aware of this when designing and managing their brands.

The final variable entitled 'evaluations' was defined as an overview of the expectations, perceptions/ associations and experiences variables. This suggested that the evaluations variable was merely an overview or replication of the previous applied findings, 'reapplied'. Nevertheless, Bosch et al. (2006a) seemed to ignore the strength and uniqueness variables in defining the evaluations variable. Bosch et al. $(2006 a, 14)$ proposed the evaluations variable referred to how brand users interpret and evaluate the brand in question and 'related marketing information', which broadly implied a reference to the strength variable without explicitly acknowledging the strength variable. Further to this, the uniqueness variable was neither explicitly implied nor implicitly referenced within the conceptualisation of the evaluations variable (Bosch et al. 2006a). To ignore the strength and uniqueness variables in the evaluation variable of the brand image of the UK Conservative Party brand questioned their relevance in the original framework. In the case of this research, the evaluations variable did not consider the 'brand identity signals' or unique meaningful attributes linked or not linked to the party, leader or policy. This disregard for the strength and uniqueness variables had the potential to overlook findings which ultimately would have provided only a partial understanding of the brand image of the UK Conservative Party brand. For consistency, future studies adopting this revised framework should include all five variables when constructing the evaluation of brand image. However, this questions the relevance of a variable that is merely a reapplication of findings otherwise known as a summary section. Therefore, the 'evaluations' variable could be removed to avoid repetition and the findings from the five variables could be summarised in the conclusion section which would lead to logical closure. 


\section{Conclusion}

Smith $(2001,992)$ argued that 'image in politics is of critical importance and as such merits further analysis.' Given there are limited tools to deconstruct brand image, greater elaboration was needed (Chen 2010; Cretu and Brodie 2007; Guzman and Sierra 2009; Henrik and Fredrik 2006; Johns and Gylmothy 2008; Knox and Freeman 2006; Poiesz 1989; Smith 2001). This paper therefore fulfils an identified problem of how to systematically deconstruct political brand image insights (Aaker and Joachimsthaler 2002; Johns and Glymothy, 2008; Gordon 1999 cited in Cowley 1999; Ross and Harradine 2011; Saaksjarvi and Samiee 2011; Srivastava 2011). This was achieved by critically applying the brand image framework (Bosch et al. 2006a) in exploration of the three elements of the UK Conservative Party brand from an external perspective.

The UK Conservative Party during the 2010 UK General Election contextualised the critique and deconstruction process. Nevertheless, the conceptualisation often required clarification, greater elaboration and rearticulation as the original version set out by Bosch et al. (2006a) was often ambiguous, somewhat flawed and lacked rigour. When applied with the political brand image, the clarified, rearticulated and simplified conceptualisation provided a deeper understanding of the operationalisation of the external orientation of David Cameron's Conservative brand. This in turn highlighted that the UK Conservative Party brand image under his leadership can be considered complex, multifaceted and often contentious, which was inconsistent with the existing literature on successful political brands (Needham 2006). Additionally, the UK Conservative Party had not managed to completely dispel the party of the rich, privileged and upper-classes perceptions and associations (Ashcroft 2010; Helm, 2010) and failed to demonstrate the desired inclusive image. However, it can be argued that David Cameron and the UK Conservative Party had come some way in decontaminating the 'Tory brand'image. Nevertheless, many questions and uncertainties (Needham 2006) remained. Thus, the brand image of the UK Conservative Party required attention following the 2010 UK General Election.

\section{Implications}

This paper provides a clarified, rearticulated and simplified conceptualisation of brand image (Table 2), which can be seen as a mechanism to explore a brand from an external orientation. This may require refinement and adaptation if transferred to other contexts. Nevertheless, this framework rather than the original conceptualisation can be used in future research to deconstruct the external orientation of a brand within and beyond the political context. This paper also offers ground for future research into the current political brand image of the UK Conservative Party to assess its development and evolution since the 2010 UK General Election. Furthermore, this research provides political parties, candidates and organisations with the opportunity to gain deeper understandings of their brands and allow them to explore the coherency between external imagery and internally created brand identity. Finally, this paper provides a detailed account of how to explore political brand image and adds to the limited studies on how brands are positioned in the mind of consumers (Guzman and Sierra 2009; Needham and Smith 2015; Smith 2001).

\section{Disclosure statement}

No potential conflict of interest was reported by the authors.

\section{Notes on contributors}

C. Pich is a Lecturer at Nottingham Trent University. He completed his PhD thesis at Hull University Business School and has published in a number of journals, including Journal of Marketing Communication and the Journal of Political Marketing.

G. Armannsdottir is a Lecturer in Marketing Nottingham Business School, Nottingham Trent University. She completed her PhD on marketing within SME's in Iceland at the University of Hull. She continues to focus her research on consumer behaviour, internal marketing and projective technique analysis. 


\section{References}

Aaker, D., and E. Joachimsthaler. 2002. Brand Leadership. London: Simon \& Schuster UK Ltd.

Alsem, K. J., and E. Kostelijk. 2008. "Identity Based Marketing: A New Balanced Marketing Paradigm." European Journal of Marketing 42 (9/10): 907-914.

Alston, M., and W. Bowles. 2007. Research for Social Workers: An Introduction to Methods. London: Routledge.

Ashcroft, M. A. 2010. Minority Verdict: The Conservative Party, the Voters and the 2010 Election. London: Biteback.

Ashcroft, M. A. 2005. Smell the Coffee: A Wake-up Call for the Conservative Party. Great Britain: CGI Europe.

Baines, P., and B. Chansarkar. 2002. Introducing Marketing Research. West Sussex: John Wiley and Sons.

Bale, T. 2011. The Conservative Party from Thatcher to Cameron. Cambridge: Polity Press.

Bloor, M., J. Frankland, M. Thomas, and K. Robson. 2001. Focus Groups in Social Research. London: Sage.

Boddy, C. R. 2005. "Projective Techniques in Market Research: Valueless Subjectivity or Insightful Reality?" International Journal of Market Research 47 (3): 239-254.

Bond, D., and E. Ramsey. 2010. "The Role of Information and Communication Technologies in Using Projective Techniques as Survey Tools to Meet the Challenges of Bounded Rationality." Qualitative Market Research: An International Journal 13 (4): 430-440.

Bosch, J., E. Venter, Y. Han, and C. Boshoff. 2006a. "The Impact of Brand Identity on the Perceived Brand Image of a Merged Higher Education Institution: Part One." Management Dynamics 15 (2): 10-30.

Bosch, J., E. Venter, Y. Han, and C. Boshoff. 2006b. “The Impact of Brand Identity on the Perceived Brand Image of a Merged Higher Education Institution: Part Two." Management Dynamics 15 (3): 36-47.

Broeckelmann, P. 2010. “Exploring Consumers' Reactions towards Innovative Mobile Services." Qualitative Market Research: An International Journal 13 (4): 414-429.

Bryman, A., and E. Bell. 2003. Business Research Methods. Oxford: Oxford University Press.

Budge, I., I. Crewe, D. McKay, and K. Newton. 2001. The New British Politics. Essex: Pearson Education.

Butler, P., N. Collins, and R. Speed. 2011. "The Europeanisation of the British Political Marketplace." Journal of Marketing Management 27 (7-8): 675-690.

Charles, G. 2009, "Conservative Party Targets Young Voters with Spotify Ad Campaign." PRWeek (Online). Accessed October 18 2009. http://www.prweek.com/uk/news/946201/Conservative-Party-targets-younger-voters-spotify-adcampaign/?DCMP=ILC-SEARCH.

Chen, Y. 2010. "The Drivers of Green Brand Equity: Green Brand Image, Green Satisfaction, and Green Trust." Journal of Business Ethics 93 (2): 307-319.

de Chernatony, L. 2007. From Brand Vision to Brand Evaluation. Oxford: Butterworth-Heinemann.

Coop, W. F. 2005. "A Question of Identity." Journal of Marketing 11 (1): 36-37.

Cretu, A. E., and R. J. Brodie. 2007. "The Influence of Brand Image and Company Reputation Where Manufacturers Market to Small Firms: A Customer Value Perspective." Industrial Marketing Management 36 (2): 230-240.

Davies, G., and R. Chun. 2002. "Gaps between the Internal and External Perceptions of the Corporate Brand." Corporate Reputation Review 5 (2/3): 144-158.

Davies, G., and T. Mian. 2010. "The Reputation of the Party Leader and the Party Being Led." European Journal of Marketing 44 (3/4): 331-350.

Day, E. 1989. "Share of Heart: What is It and How Can It Be Measured?." Journal of Consumer Marketing 6 (1): 5-12.

Daymon, C. and I. Holloway. 2011. Qualitative Research Methods in Public Relations and Marketing Communications. New York: Routledge.

Denham, A., and K. O'Hara. 2007. "The Three'Mantras':'Modernisation'and the Conservative Party." British Politics 2: $167-190$. doi:10.1057/palgrave.bp.4200057.

Dermody, J., S. Hanmer-Lloyd, and R. Scullion. 2010. "Young People and Voting Behaviour; Alienated Youth and (or) an Interested and Critical Citizenry." European Journal of Marketing 44 (3/4): 421-435.

Einstein, M. 2008. Brands of Faith: Marketing Religion in a Commercial Age. Oxon: Routledge.

Flick, U. 1998. An Introduction to Qualitative Research. London: Sage.

French, A., and G. Smith. 2010. "Measuring Political Brand Equity: A Consumer Oriented Approach." European Journal of Marketing 44 (3/4): 460-477.

Gillham, B. 2005. Research Interviewing: The Range of Techniques. Berkshire: Open University Press.

Gordon, W. 1999. "Assessing the Brand through Research." In Understanding Brands, edited by D. Cowley. London: Kogan Page.

Gorman, G.E., and P. Clayton. 2005. Qualitative Research for the Information Professional. London: Facet Publishing.

Guzmán, F., and V. Sierra. 2009. "A Political Candidate's Brand Image Scale: Are Political Candidates Brands?" Journal of Brand Management 17 (3): 207-217.

Harris, P., and A. Lock. 2010. "'Mind the Gap": The Rise of Political Marketing and a Perspective on Its Future Agenda." European Journal of Marketing 44 (3/4): 297-307.

Helm, T. 2010. “Cameron to Pledge NHS Cash Boost for Poorest." The Observer, January 3, 2010: 1-8.

Henrik, S., and T. Fredrik. 2006. "When Communication Challenges Brand Associations: A Framework for Understanding Consumer Responses to Brand Image Incongruity." Journal of Consumer Behaviour 5 (1): 32-42. 
Johns, N., and S. Gylmothy. 2008. "Assessing the Brand Position of Danish Kros." Journal of Vacation Marketing 14 (3): $257-281$. Jones, D. 2010. “Karaoke Cameron." The Mail on Sunday Two, January 3, 2010: 1-4.

Kavanagh, D. 2000. British Politics: Continuities and Change. Oxford: Oxford University Press.

Keller, K. L. 1993. "Conceptualizing, Measuring, and Managing Customer-Based Brand Equity." Journal of Marketing 57: 1-22.

Knox, S., and C. Freeman. 2006. "Measuring and Managing Employer Brand Image in the Service Industry." Journal of Marketing Management 22 (7-8): 695-716.

Krueger, R. A. 1998. Analyzing and Reporting Focus Group Results. London: Sage.

Kvale, S. 1996. An Introduction to Qualitative Research Interviewing. London: Sage.

Langford, J., and D. McDonagh. 2003. Focus Groups: Supporting Effective Product Development. London: Taylor and Francis. Lee, S., and M. Beech. 2009. The Conservatives under David Cameron: Built to Last? Hampshire: Palgrave Macmillan.

Lock, A., and P. Harris. 1996. "Political Marketing - Vive La Difference." European Journal of Marketing 30 (10/11): 21-31.

Malhotra, N. K., and D. F. Birks. 2003. Marketing Research: An Applied Approach. Essex: Pearson Education.

McEnally, M., and L. de Chernatony. 1999. "The Evolving Nature of Branding: Consumer and Managerial Considerations." Academy of Marketing Science Review 2: 1-30.

Mengxia, Z. 2007. "Impact of Brand Personality on PALI: A Comparative Research between Two Different Brands." International Management Review 3 (3): 36-46.

Morgan, N., A. Pritchard, and R. Piggott. 2002. "New Zealand, 100\% Pure. the Creation of a Powerful Niche Destination Brand." Journal of Brand Management 9 (4): 335-354.

Mortimore, R., P. Baines, I. Crawford, R. Worcester, and A. Zelin. 2014. "Asymmetry in Leader Image Effects and the Implications for Leadership Positioning in the 2010 British General Election." International Journal of Market Research 56 (2): $185-205$.

Nandan, S. 2005. "An Exploration of the Brand Identity-Brand Image Linkage: A Communications Perspective." Journal of Brand Management 12 (4): 264-278.

Needham, C. 2006. "Brands and Political Loyalty." Journal of Brand Management 13 (3): 178-187.

Needham, C., and G. Smith. 2015. "Introduction: Political Marketing." Journal of Political Marketing. doi:10.1080/1537785 7.2014.990828.

Nilson, T. H., and N. C. L. Surrey. 1998. Competititve Branding: Winning in the Market Place with Value-Added Brand. Chichester: John Wiley and Sons.

Peng, N., and C. Hackley. 2009. "Are Voters, Consumers? A Qualitative Exploration of the Voter-Consumer Analogy in Political Marketing." Qualitative Market Research: An International Journal 12 (2): 171-186.

Pettigrew, S., and S. Charters. 2008. "Tasting as a Projective Technique." Qualitative Market Research: An International Journal 11 (3): 331-343.

Petromilli, M., and D. Michalczyk. 1999. "Your Most Valuable Asset." Marketing Health Service 19 (2): 4-9.

Phipps, M., J. Brace-Govan, and C. Jevons. 2010. "The Duality of Political Brand Equity." European Journal of Marketing 44 (3/4): 496-514.

Pich, C., D. Dean, and P. Punjaisri. 2014, "Political Brand Identity. An Examination of the Complexities of Conservative Brand and Internal Market Engagement during the 2010 UK General Election Campaign." Journal of Marketing Communications. doi:10.1080/13527266.2013.864321.

Poiesz, T. B. C. 1989. "The Image Concept: Its Place in Consumer Psychology." Journal of Economic Psychology 10: 457-472.

Ramsey, E., P. Ibbotson, and P. McCole. 2006. "Application of Projective Techniques in an e-Business Research Context." International Journal of Market Research 48 (5): 551-573.

Rawson, E. A. G. 2007. "Perceptions of the United States of America: Exploring the Political Brand of a Nation." Place Branding and Public Diplomacy 3 (3): 213-221.

Rekom, J. V., G. Jacobs, P. W. J. Verlegh, and K. Podnar. 2006. “Capturing the Essence of a Corporate Brand Personality: A Western Brand in Eastern Europe." Journal of Brand Management 14 (1/2): 114-124.

Reeves, P., L. D. de Chernatony, and M. Carrigan. 2006. "Building a Political Brand: Ideology or Voter-Driven Strategy." Journal of Brand Management 13 (6): 418-428.

Robinson, J. 2004. "Repackaging Our Politicians: Marketing MPs in an MMP World." New Zealand Marketing Magazine 23 (5): 12-19.

Ross, J., and R. Harradine. 2011. "Fashion Value Brands: The Relationship between Identity and Image." Journal of Fashion Marketing and Management: An International Journal 15 (3): 306-325.

Sääksjärvi, M., and S. Samiee. 2011. "Relationships among Brand Identity, Brand Image and Brand Preference: Differences between Cyber and Extension and Retail Brands over Time." Journal of Interactive Marketing 25: 169-177.

Schneider, H. 2004. "Branding in Politics - Manifestations, Relevance and Identity-Oriented Management." Journal of Political Marketing 3 (3): 41-67.

Schutt, R. K. 2004. Investigating the Social World: The Process and Practice of Research. London: Sage.

Smith, G. 2001. "The 2001 General Election: Factors Influencing the Brand Image of Political Parties and Their Leaders." Journal of Marketing Management 17: 989-1006.

Smith, G. 2005. "Positioning Political Parties: The 2005 UK General Election.” Journal of Marketing Management 21: $1135-1149$.

Smith, G. 2009. "Conceptualizing and Testing Brand Personality in British Politics." Journal of Political Marketing 8 (3): $209-232$.

Smith, G., and A. French. 2011. "Measuring the Changes to Leader Brand Associations during the 2010 Election Campaign." Journal of Marketing Management 27 (7-8): 718-735. 
Srivastava, R. K. 2011. “Understanding Brand Identity Confusion." Marketing Intelligence and Planning 29 (4): $340-352$.

Stewart, D. W., and P. N. Shamdasani. 1990. Focus Groups: Theory and Practice. London: Sage.

Van Gelder, S. 2003. Global Brand Strategy: Unlocking Branding Potential across Countries, Cultures and Markets. London: Kogan Page.

Van Ham, P. 2001. "The Rise of the Brand State: The Postmodern Politics of Image and Reputation." Foreign Affairs 80 (5): 2 -6. Warren, C. A. B., and T. X. Karner. 2005. Discovering Qualitative Methods: Field Research, Interviews and Analysis. Los Angeles, CA: Roxbury.

Worcester, R., R. Mortimore, P. Baines, and M. Gill. 2011. Explaining Cameron's Coalition. London: Biteback. Zikmund, W. G. 2003. Business Research Methods. Ohio: Thomson Learning South-Western. 